\title{
A Suitable Paradigm: the Indian Founding and the world
}

\author{
James Fowkes ${ }^{1} \mathbb{D}$
}

Accepted: 16 December 2021 / Published online: 12 January 2022

(c) The Author(s) 2022

\begin{abstract}
What is the relevance of the Indian case for South Africa? And what should South Africans, and the rest of the world, make of the claim in Madhav Khosla's India's Founding Moment that we should recognize India as 'the' paradigm case for modern constitutional democracy? The constitutional projects of India and South Africa are naturally connected, but Khosla's book helps to bring out what is perhaps the most important of the connections. Both are founded on an insistently democratic constitutionalism, in places where most inhabitants had long been told they were not suited or ready for democracy. Both display the conviction that boldly giving the vote to all, in these circumstances, is a powerful way to construct a democracy. This idea is crucial for understanding many aspects of both constitutions. This makes India a natural paradigm case for South Africa and many others. The stronger claim, that it is 'the' paradigm case and should succeed the United States to this status, can become more complicated once one tests it out globally (like the US claim). Finland and Ireland are especially strong and earlier examples of what Khosla sees as ground-breaking in India. Latin America's somewhat different post-colonial trajectory makes India a more imperfect paradigm there. But that said, treating India and its founding as paradigmatic may well be the single best step to take for a more balanced view of the constitutional world, and this book's elegant erudition makes it a real scholarly pleasure to do so.
\end{abstract}

Keywords Comparative Constitutional Law $\cdot$ Democracy $\cdot$ Post-colonialism · India · South Africa · United States

\section{Introduction}

Sometimes, comments on a book test the book's claims on the way to rebutting them, wholly or in part. This contribution is not one of those. Instead, it is about testing two claims that I find very plausible, in order to try and decide just what to

James Fowkes

fowkes@uni-muenster.de

1 Professor of Foreign and International Law, University of Münster, Münster,

Nordrhein-Westfalen, Germany 
make of them. One of these claims is about the connections between Madhav Khosla's book on India's founding, and the case of South Africa, the one I know best. ${ }^{1}$ The other is Khosla's claim that we should recognize India's paradigmatic status for twentieth-century constitutional democracy.

I have little doubt about the plausibility of either claim. It is easy enough to connect India and South Africa. It is also easy to see why India should be a really key global example, given its size and the interest and influence of its constitutionalism and its revolutionary leaders and the historical moment at which that constitution emerges. I also have little doubt that the world does not currently reflect the correctness of these two claims as much as it should. Scholars of the South African constitution do not pay enough attention to India, notably including the aspects on which Khosla's book focuses, and nor does comparative constitutional law in general. That alone is reason enough for him to have written his book, and for the rest us to be pleased we have a book of this quality to read on the topic, from its splendid subtitle on down.

But for those already convinced of the need to pay serious attention to India, the most interesting question is not whether to accept these claims as broadly correct and important, but what to do with them once we accept them. What exactly should South Africans draw from the Indian example, and from Khosla's account of his chosen aspect of it-given that the connections are obvious, but that there are also obvious differences? What exactly should the rest of us, outside India, make of the idea that India is the modern paradigm case of democratic constitutionalism-with its implication that it is our paradigm, too?

In this contribution, I will argue that Khosla's account of the Indian case, and his focus on the democratic constitutional vision of its founders, can help South Africans refocus on closely related elements of their own constitutionalism which they have been neglecting. This is as good an illustration as any of India's relevance and value as a paradigm case. But Khosla's contention that India is the paradigm case for the twentieth century is a bigger claim. If we take a global view, other examples (especially Ireland and Finland) will cut it down to size somewhat. Even then, however, a very substantial claim will be left standing. We do not, of course, have to pick just one paradigm case for the twentieth century, and we will do better not to- - but if we did, I see no example with a better claim to that status than India.

\section{On being ready for democracy: India and South Africa}

Let's start with the South African link. And let's take as given the broad parallels between India and South Africa: that each was home to one of the great and admirable national liberation movements of the twentieth century; that each of those movements used its mass mobilized power to establish a new constitutional order; that each has seen a serious effort to do constitutionalism in the context of poverty and inequality and the legacies of past colonial regimes and present post-colonial realities; and that each has been influential and symbolically important for these reasons. Details aside, basic parallels like these are clear.

\footnotetext{
${ }^{1}$ Khosla 2020.
} 
Khosla's book, however, has a narrow and sharper focus than this. Drawing out the parallels between his particular account and the South African case takes a little more work - but as we will now see, this work is very well worth doing.

In addition to the obvious parallels already noted, India and South Africa share two other similarities when it comes to constitutional scholarship. First, each currently suffers from a disproportionate focus on aspects of the founding years that are of great significance but nevertheless loom larger in the whole story than they should. In the Indian case, as Khosla argues, these include partition. ${ }^{2}$ In South Africa's, they include the constitutional negotiations and the certification process. In each case, these are truly important issues that have commanded attention to a degree that exceeds their true importance. ${ }^{3}$

Second, constitutional discussion of each case is more court centric than it should be. While Indian constitutionalism does not receive as much attention as it should, it certainly receives some. But much of it is focused on the Supreme Court: on the basic structure doctrine and public interest litigation and the right to food case and all the rest of them. The pattern in writing on South Africa is comparable. The country also receives significant attention from constitutional scholars. But though foreigners tend to be more admiring and locals tend to be more critical, it is the Constitutional Court about which they all usually speak. In both India and South Africa, other institutions and forces are often talked about in terms of their relation to the highest court rather in their own right, if they are talked about at all. ${ }^{4}$

Khosla's book, offered as a corrective to these problems in the Indian context, can also help to be a corrective in the South African one. His Indian account focuses attention on a part of the story that is neglected and revisionary in the South African case, too.

Khosla never looks beyond 1950, because his interest is the experiment, before it was known what would come of it. He wants us to appreciate the constitutional leap of democratic faith the Indian founders made and then to consider the ways they hedged that faith with institutional choices (for example, with an ultra-long, codelike constitution). ${ }^{5}$ He wants to consider that act of faith on its terms and in its own moment.

Presumably, our interest in this has at least something to do with the success of the leap. For instance, the challenges for democracy in Indian society circa 1950 are so striking to read about precisely because of the degree to which Indian democracy succeeded in the face of them. But that is only an implicit premise in Khosla's argument. What happened after 1950 might be a reason why he and we take up the topic, but it is of course strictly irrelevant to the exercise of seeing the Indian founding as the founders themselves saw it.

\footnotetext{
2 Khosla 2020, pp. 15-17, 112-14.

3 I have not yet published all the evidence necessary to support this claim in the South African context, but see Fowkes 2016, pp. 95-121 and Fowkes 2020.

4 This concern informs my argument in Fowkes 2016 although, as I noted there, 'as an effort to challenge the predominantly Court-centric scholarship, this book has shared some of the sins of its target.' ibid, p. 351.

5 Khosla 2020, pp. 30-43.
} 
Since the subsequent work of courts is part of what this perspective excludes, it forces us away from court centrism. It also creates at least some distance to overemphasized issues like partition in India and negotiated constitution-drafting in South Africa, though it does not, of course, make them irrelevant. It compels us to focus on the original, political act of constitutional creation and construction: on the decision of the leaders of two extraordinary national liberation movements, at the peak of their powers, to found their reborn countries on a constitution. ${ }^{6}$

And to found them - this is the part where Khosla's contribution is greatest from a South African perspective-on an insistently democratic constitution. In both India and South Africa, Western colonialism had come to a place and told the people already there that they were not ready for democracy and self-governance. For centuries, the line from those in power was that India and South Africa could only be functioning countries if led by white officers. From this perspective, real democracy was impossible, inappropriate and irresponsible.

In these circumstances, majority leaders in both countries came to see the principle of democratic self-determination as more than important. They came to see it as ultimate.

There can be great dangers to this sort of thinking. It can prefer ideas that are 'ours' to ideas that work. Khosla notes Gandhi's panchayat economics, for example: an approach which, like Julius Nyerere's ujamaa policies in Tanzania, made rather more sense as a search for a distinct post-colonial identity than it ever did as an economic plan. ${ }^{7}$

But there can also be magic to this thinking-because if we are determined to treat democratic self-government as ultimate, then we will also see it as ultimate over challenges and adverse conditions. To build up a resistance to lifetimes of being told that one is not ready for democracy and self-government is to build up a resistance to the idea of unreadiness itself. That has sometimes made post-colonial leaders dangerously impractical. But it also underwrote the acts of faith in democratic governance in post-colonial India and post-apartheid South Africa, in contexts where even non-bigots could find many plausible reasons to think that ordinary democracy would not work.

What brings the argument full circle is that this act of faith and imagination and idealism can itself be intensely practical. It is not just that it can be combined with practical thinking, though this is crucial in both India and South Africa. Both countries benefitted from leaders and constitutional thinkers who made serious room for realism and pragmatism amidst the idealism and the ideology. Much of Khosla's book is about this: about how serious people and serious lawyers who had decided that India was going to be a full democracy-period-thereafter took the next steps of making specific decisions about how to draft a constitution that could best govern that full democracy. There are at least some broader parallels to South Africa here, although of course in the details there are many differences. One will find a similar instinct to centralize power in order to be able to transform society, for example, and

\footnotetext{
6 The comparison in these terms has been recently stressed by Ackerman 2019, chapters 2 and 3.

7 Khosla 2020, pp. 79-90.
} 
a similar need for constitutionalism to work to build institutions and norms, and not just to protect or co-ordinate already established ones. ${ }^{8}$

But the deepest connection to South Africa is in the underlying impulse: in the ultimate idea that the act of insisting on being a democracy is a powerful way to become one. To be sure, there is no shortage of discouraging examples to show that this does not mean that you can become a democracy just if you believe hard enough that you are one. But endowing oppressed and excluded people with the vote is an act of empowerment that can create the citizens necessary for a democracy. ${ }^{9}$ Democracy is something made by being and doing, just as there is no way to create trust without trusting, and no way to learn parenting except to be already responsible for a child. All the debates about whether Indians and black South Africans were ready for democracy and self-government in practice were met-were answered-with the steadfast reply that they were ready for these things in principle.

As I have begun to argue elsewhere, the way in which the South African case is remembered and understood makes too little room for the constitution as the constructive revolutionary act of a mass mobilized movement. ${ }^{10}$ At the core of this idea must lie an inclusive account of democracy asserted in response to an exclusionary past. That idea, at once political and constructively legal, is been the principal casualty of the disproportionate focus on the negotiated transition and the court centrism noted earlier. ${ }^{11}$ Khosla's account of India's founding, with its emphasis on democratic citizenship, will help South Africans and their many friends overseas to see the South African constitutional founding for what it truly was.

\section{India in global perspective}

But Khosla wants to claim more. His claim is not just that India is an instructive analogy for a case with clear similarities like South Africa, or that Indians themselves would do well to pay more attention to their founding as a revolutionary act. Indeed, his claim is not just that constitutionalists around the world should talk about New Delhi and B. R. Ambedkar at least something like as often as they talk about Philadelphia and James Madison. He makes a stronger claim: that India should be treated as the twentieth-century paradigm for democratic constitutionalism in the way that US has been treated as its paradigm in an earlier age:

The historical conditions of India's creation should encourage us to see it as the paradigmatic democratic experience of the twentieth century, in much the

\footnotetext{
8 ibid e.g. pp. 36, 73-74.

9 'To limit the franchise, Ambedkar believed, was to misunderstand the meaning of democracy. It was to proclaim that democracy was solely about the expression of preferences at the ballot box...Instead... Ambedkar turned to John Dewey to underline the relationship between democracy and participation.' ibid, p. 11.

10 As Khosla comments about India: 'One reason the Indian founding has rarely been interrogated is that it has often not been regarded as the site of revolution'. Ibid, p. 25.

11 Among other things. For constructive revolution, see Arendt 1963.
} 
same way that Tocqueville had seen the United States as the model nineteenthcentury democracy. ${ }^{12}$

This argument asks South Africans, and many others in the constitutional world, to see India not just as an important and relevant case, but as their paradigm: as paradigmatic of the constitutionalism that they are doing. This claim seeks to position India as the most important case of constitutional democracy in living memory for most states, while also quietly consigning the previous US incumbent to a dusty, albeit honourable, retirement.

This is a (no doubt deliberately) provocative claim, made more so by the fact that Khosla's focus is mostly on giving the Indian founding the detailed attention the claim implies it deserves, rather than on working out the claim itself. So what should we make of it?

To start with, what do we make of the claim that India is paradigmatic, given that it is also often portrayed as exceptional? Khosla, like others before him, presents India as a 'most surprising democracy' given the extraordinary obstacles Indian faced and faces, and its unsurpassed combination of size and diversity. India's constitution is also an outlier in some legal respects: its sheer length, for example, or the way it includes socio-economic interests, but not as justiciable rights. ${ }^{13}$ India's success as a democracy, too, makes it unusual relative to most other states in the post-colonial world. Witness the fact that if we were after an average case, Pakistan might well be the better South Asian system to choose.

India, then, is not paradigmatic for Khosla because it is a median constitutionany more than is true for the US, which is and has always been a global outlier in important respects too. On the other hand, it does matter for Khosla's argument that India is more like most other states in recent history than the US is. He distinguishes India from the British Empire's former white Dominions, and from several other notable post-WW II examples (Germany, Japan, Israel), on the basis that India's social and economic context is far more representative of the conditions in the wave of decolonizing states in Africa and Asia. ${ }^{14}$

But what exactly is it, for this large block of states that can be said broadly to share India's socio-economic conditions, that makes India paradigmatic? More specifically, given Khosla's focus, what it is about India's founding moment that makes it paradigmatic in the same way that the US was paradigmatic for an early generation of emerging democratic states?

The best answer, it seems to me, is to understand Khosla to be using 'paradigm' in something like the way 'paradigm case' is used in analytic philosophy. ${ }^{15}$ In that context, a paradigm case is used to argue that a term must have at least some meaning. If we all use a term at least to apply to one case, the paradigm case, then that shows that the term is meaningful, at least to that extent. If we all think that a laughing child is happy, then there must be such a thing as happiness and it must be that

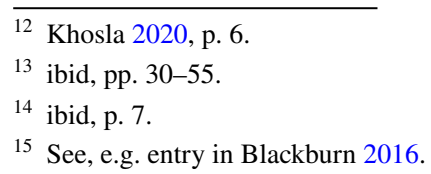


the term is not meaningless, even if we disagree or are uncertain about many other aspects of the idea and its application.

The US and India are both paradigms because they proved that an idea was meaningful and could be realized in the world, in the face of the conventional constitutional wisdom of their eras. The US was an effort, in a world of monarchies, to try and do constitutionalism on purely republican principles, an effort that would slowly turn more democratic. For many, at the time of founding and long after it, this was an inherently unstable constitutional model, bound to fail. But it did not, and we treat the US as the key case-as the paradigm case - that proved, in the face of tradition and skepticism, that the idea is workable.

Khosla argues that India, in its own way, is a first as the US was a first: that the Indian founding is 'the historical node at which democracy, constitutionalism, and modernity occurred simultaneously'. ${ }^{16}$ It, therefore, has a similar claim to paradigm status, but in relation to a more modern phenomenon. India's 'first' is more relevant to most states today, when democracy is the norm, than is a US 'first' that had much to do with puzzles over republicanism and sovereignty and society that today it can take effort even to recall. ${ }^{17}$

There is a certain post-colonial relish to the claim that Indians, long told by the West that they were unready for democracy, succeeded by entrusting their constitutional experiment to universal democracy far more readily than the West had been at comparable moments in its history. And if by the 'West' here we mean the US or the UK, the only examples besides India that Khosla considers in any detail, the claim is certainly true. Both did establish their constitutions first and introduce democracy only incrementally and only later.

If we consider other cases besides these, however, the contrast gets a good deal less sharp.

First, we might consider a set of earlier cases from the centre of Europe, where several states introduced universal suffrage rather suddenly in the wake of the Russian Revolution and/or World War I: Germany, Austria, the post-WW I Czechoslovak state, Poland, and indeed the Soviet Union itself, if we choose to count it as a sincere democratic experiment at the beginning. Of course, this is not a list of states introducing universal suffrage with their first constitutions. But since India had constitution-like governing statutes before independence, we might argue that India in 1950, like these cases, was really undergoing an extraordinary change in constitutional regime, from an earlier regime not based on popular sovereignty and democracy to one that credibly was. That would be a fair way to describe Weimar Germany's dramatic shift from imperial state to republic in 1919, for example. Poland's 1919 constitution, in turn, is only not its first if you count the doomed 1791 constitution, never really in force before Austria, Prussia and Russia crushed it. In short, if we adjust the formal terms of the comparison a little, there are earlier examples of a sudden bold shift to constitutionalism with a universal franchise. One could argue

\footnotetext{
16 Khosla 2020, p. 24.

17 As Gordon Wood pointed out some years ago, '[The American Revolution] was as radical and social as any revolution in history, but it was radical and social in a very special eighteenth-century sense.' Wood 1992, p. 5.
} 
that Indian conditions circa 1950 were even more challenging for democracy than they were in these post-WW I cases, but any difference will be a matter of degree.

Khosla seems to follow several of the Indian founders in sidelining cases like these, instead, because they failed as democracies. ${ }^{18}$ If paradigm cases are those that prove something can work, these cases didn't. India is the paradigm, because India succeeded.

But that still leaves two states that represent clearer counterexamples, on the bare facts, to Khosla's claims about India's 'first': Ireland and Finland. Like Indians, but earlier, the Irish were long seen as a lesser race by their British colonizers and were ruled with a mix of force and condescension accordingly. Most of Ireland broke away, introduced universal suffrage by 1923, and had its own constitution by 1937 . Finland, earlier still in a different imperial context, introduced universal suffrage when it became an autonomous principality of the Russian Empire in 1906, ahead of its independence constitution in 1917. Neither democracy is without its disruptions thereafter (as India is not), but both endure from that point.

In neither case, of course, was the introduction of constitutionalism and democracy as neatly simultaneous as it was in India. But if one is trying to defend India's status as a boldly democratic first, the disjunct is in the wrong direction: both Ireland and Finland introduced universal suffrage as soon as they had the power to do so, even before infrastructure such as the constitution itself was in place. This is the opposite of doing constitutionalism first and democracy only slowly and only later. ${ }^{19}$

Perhaps it matters that these potential counterexamples are European: that even if they are earlier, India is still the first post-colonial case, the first simultaneous introduction of constitutionalism and universal suffrage in the wake of Western colonialism. But excluding Finland and Ireland on this basis may have more to do with how we use terms like 'colonial' than it does with the facts. ${ }^{20}$ After all, Finland and Ireland (among quite of number of other European countries) are examples of states or peoples which attained their independence after centuries of foreign imperial domination and exploitation. If we are interested in the introduction of constitutionalism based on popular sovereignty and universal suffrage in substantially peasant societies in the wake of foreign dominance, it is not obvious on the bare facts that European cases like these are less interesting or less relevant than India.

It is more obvious on the facts as interpreted in light of how we understand standard categories like 'colonial' or 'Global North/Global South', and the importance we assign to those categories. In this context, the Indian case has the advantage of being able to serve as a corrective to a Western bias in comparative constitutional law, in a way that Ireland or Finland could not (even though they, too, are often marginalized). India's paradigm status depends in part on the fit it has, relative to other cases, with hegemonic patterns in how we speak and think. That meshes both

\footnotetext{
18 Khosla 2020, pp. 1, 6, 46, 55, 89, 93, 122-23.

19 It is, however, worth asking whether not introducing the two simultaneously reflects, not just coincidental historical variation, but a different view about what is needed to establish a constitutional democracy, compared to Indian thinking. If so, Khosla would have a further reply to these counterexamples.

${ }^{20}$ For a small effort to cut across these habits and apply post-colonial thinking to post-Soviet Europe, see Fowkes and Hailbronner 2019.
} 
with Khosla's view of India as especially relevant for the states produced by the post-1945 decolonial wave, and with his emphasis on how the leap of faith of India's founders was taken in the face of colonial expectations.

Finally, there is the question of Latin America. The region, with different colonial patterns, came far earlier to independence and constitutionalism than India. Indeed, it is too early for states here to match India's simultaneous introduction of democracy and constitutionalism: like the US, Latin American states enacted their independence constitutions long before democracy became the global norm. But if that leaves Khosla's claim about India's first unchallenged by these examples, it also makes India's founding less paradigmatically relevant for them. (Other aspects of the Indian case, such as doing constitutionalism in the context of social inequality, are of course more relevant, but in those respects, India is neither distinctive in Latin American perspective nor first by many years).

It is quite easy to defend India's status as the most significant case of the postWW II decolonial wave in Asia and Africa, based on its size and its unusual (almost unique) degree of constitutional democratic success among states in this category. It is harder to defend it as the most significant case of post-colonial constitutionalism in general. Latin American examples, where we use colonial terminology much more naturally than in European contexts, make this point more clearly than Ireland or Finland. But Latin American examples face other obstacles as potential rival paradigms. India is a standout constitutional case in South Asia, in Asia generally, and in the former British world system. There is no comparable single, large, standout case in Latin America. (Brazil may be distinctively big in its region, but it has not been distinctively more successful as a constitutional democracy.) Furthermore, colonial discussion today often focuses on the post-WW II trend, which Latin America does not fit. And Latin America is furthered hindered by the hegemony of English in scholarship, one final coincidental factor that, in turn, supports India's paradigm status. $^{21}$

Including India as a paradigm is a step towards a more balanced view of the constitutional world. It is a crucial step. Indeed, it may very well be the single best first step in that direction: I can think of no better one to take. In that fact lies the single best reason to accept Khosla's strong form claim that it is the paradigm case of twentieth-century constitutional democracy. But to take that step is still only to take one step.

\section{Conclusion: A paradigm like the United States}

The enquiry of the last section has taken us far from Khosla's main project in his book, though it seems to me an important part of deciding where to fit his work into a broader constitutional picture. One might conclude from it that India's claim to paradigm status is weakened, once we see it in the context of these other examples_-at least, pending a more detailed comparative enquiry. To my mind, however,

${ }^{21}$ For a Latin American argument about these patterns, directed principally against the dominance of the US paradigm, see Bonilla Maldonado 2013. 
we should draw a different conclusion. What the discussion here really establishes is how thoroughly and perhaps unintentionally accurate it is to claim that the India is a paradigm in the same way as the US is a paradigm.

In both the US and Indian cases, the claim to be first to an important constitutional milestone does have meaningful content-but the matter also gets less decisively clear the more one looks at it in truly global perspective, rather than the national mindset that people tend to use when writing about their own countries. In both cases, their plausibility as paradigms lies in addition in their being big, important countries whose legal systems operate in English. India is also becoming more like the US in generating a body of high-quality English-language scholarship about itself, a mostly recent development of which Khosla's book is as fine an example as any. Like the US, India's paradigm status has at least something important to do with its position in relation to hegemonic concepts and other global power dynamics, from which it is positioned to benefit more than most.

And there is, at least for me, one further respect in which India is a paradigm like the US, and it is one that takes us back to the heart of this book.

As a comparative constitutional example, the US is often embattled. Some begrudge its status and emphasize its oddities; others set themselves to displace it in favour of other examples. Such arguments are often made for good reasons. But speaking for myself, they have only ever made sense as arguments for studying other cases too. If they are arguments for studying other cases instead, they miss the simple fact that the US is just fascinating. For constitutional lawyers, it is endlessly instructive, and endlessly interesting, whether at its best, at its worst, or when milling around uncertainly in between.

I see my arguments about where India fits in relation to other cases as I see those arguments in relation to the US. They matter for a balanced global view. But they also should not detract in the least from the simple fascination of the Indian example in itself, as they should not obscure this about the much more disproportionately studied US case. Among the pleasures of studying the US has long been the sheer quality of its scholarship. In the elegant erudition of India's Founding Moment, we can find the same pleasure in recapturing another paradigmatic constitutional morning in the world.

Funding Open Access funding enabled and organized by Projekt DEAL.

Conflict of interest On behalf of all authors, the corresponding author states that there is no conflict of interest.

Open Access This article is licensed under a Creative Commons Attribution 4.0 International License, which permits use, sharing, adaptation, distribution and reproduction in any medium or format, as long as you give appropriate credit to the original author(s) and the source, provide a link to the Creative Commons licence, and indicate if changes were made. The images or other third party material in this article are included in the article's Creative Commons licence, unless indicated otherwise in a credit line to the material. If material is not included in the article's Creative Commons licence and your intended use is not permitted by statutory regulation or exceeds the permitted use, you will need to obtain permission directly from the copyright holder. To view a copy of this licence, visit http://creativecommons.org/ licenses/by/4.0/. 


\section{References}

Ackerman B (2019) Revolutionary Constitutions: Charismatic Leadership and the Rule of Law. Belknap Press of Harvard University Press, Cambridge MA \& London

Arendt H (1963) (2006) On Revolution. Penguin Classics, London

Bonilla Maldonado D (2013) Introduction: Towards a Constitutionalism of the Global South. In: Bonilla Maldonado D (ed) Constitutionalism of the Global South: The Activist Tribunals of India, South Africa, and Colombia. Cambridge University Press, pp 1-40

Fowkes J (2016) Building the Constitution: The Practice of Constitutional Interpretation in Post-Apartheid South Africa (CUP, 2016)

Fowkes J (2020) Choosing to have had a Revolution: Lessons from South Africa's Undecided Constitutionalism' In: Albert R (ed), Revolutionary Constitutionalism: Law, Legitimacy and Power (Hart, 2020)

Fowkes J, Hailbronner M (2019) Decolonizing Eastern Europe: a global perspective on 1989 and the world it made'. Int J Const Law 17:497-509. https://doi.org/10.1093/icon/moz040

Khosla M (2020) India's Founding Moment: The Constitution of a Most Surprising Democracy. Harvard University Press, Cambridge MA \& London

Wood G (1992) The Radicalism of the American Revolution. Vintage Books, New York

[no author given] Paradigm case argument (2016). In: Blackburn S (ed), Oxford Dictionary of Philosophy, $3^{\text {rd }}$ edn. Oxford University Press. [No page number given]

Publisher's Note Springer Nature remains neutral with regard to jurisdictional claims in published maps and institutional affiliations. 